\title{
Management of the Center for Early Childhood Education Development in Improving the Quality of Early Childhood Education in Jambi Province
}

\author{
Mukhtar \\ Universitas Islam Negeri Sulthan Thaha Saifuddin Jambi \\ e-mail:mukhtar@uinjambi.ac.id \\ Hidayat \\ Universitas Islam Negeri Sulthan Thaha Saifuddin Jambi \\ e-mail: hidayat@uinjambi.ac.id \\ Duyardin \\ Universitas Islam Negeri Sulthan Thaha Saifuddin Jambi \\ e-mail: duyardinmp@gmail.com \\ Article History: Received on 24 September 2020, Revised on 25 September 2020, \\ Published on 29 September 2020
}

\begin{abstract}
This study determined 1) why the Jambi Province Early Childhood Education and Community Education have not been able to improve the quality of Early Childhood Education; 2) how is the management of the Jambi Province Early Childhood Education and Community Education Partnership in improving the quality of Early Childhood Education; 3) how is the quality improvement by Jambi Province Early Childhood Education and Community Education in Jambi Province; 4) how to manage Jambi Province Early Childhood Education and Community Education to improve the quality of Early Childhood Education. This research used descriptive qualitative method, with a phenomenological-naturalistic approach. Sampling was taken by purposive sampling. The results showed that Jambi Province Early Childhood Education and Community Education Jambi Province have implemented management to improve the quality of Early Childhood Education in Jambi by implementing quality management starting from planning, organizing, implementing and monitoring which refers to TQM in Education, but in the process and the results were not optimal and not yet able to provide consumer's satisfaction.
\end{abstract}

Keywords: Management, Early Childhood Education, Community Education, Quality Education

\section{A. Introduction}

To achieve educational goals optimally, education as a means of developing the quality of human potential needs to rely on quality management. Managerial mastery, ability and orientation to plan, organize, communicate, motivate, direct and supervise which are carried out continuously are efforts to improve the quality of education, especially early childhood education.

Early childhood education or better known as children aged 0-5 years is a very decisive age in shaping the character and personality of children. The first five years are a period of rapid brain development their memory is very high, even research calls it the golden age or the 
golden age because children's intelligence reaches 50 percent at this time (Directorate General of External Education, Ministry of National Education, 2006).

Law on the National Education System No. 20 of 2003 article 1 point 14 states that Early Childhood Education is implemented before the basic education level, and Early Childhood Education can be organized in the formal education pathway (such as kindergarten, Raudhatul athfal or other forms of the equivalent), non-formal education channels (such as child care parks, playgroup or other equivalent.

According to Mukhtar Latif in his book entitled Educator Management Theory (2018) says that education has a major contribution in various aspects of national life, so education requires management as an effort to achieve its goals. Education management is known as education management. It is hoped that the quality education management can provide graduate user satisfaction.

Mulyasa (2011) stated that the success or failure of a school in achieving its goals and realizing its vision and mission lies in how the management of a school principal, especially in mobilizing and empowering various components of the school (Mulyasa, 2011; Asvio et.al, 2019). Education as one of the conscious efforts to build quality human resources to compete (Tobari et.al. 2018). Education quality management should be a priority to improve the quality of education. The concept of education quality management can be seen from changes in behavior which include cognitive, affective, and psychomotor as evidenced by the role of students in community life (Barnawi, 2017).

The Center for Early Childhood Education and Community Education Development is an institution or agency assigned by the government as a technical implementing unit of the Ministry of Education and Culture of the Republic of Indonesia in the field of early childhood education development under the Directorate General of Early Childhood Education to develop quality of early childhood education.

The duties of the Center for Early Childhood Education and Community Education Development as stated in the Regulation of the Minister of Education and Culture of the Republic of Indonesia Number 5 of 2017 concerning Organization and Work Procedure of the Early Childhood Education and Community Education Development Center to carry out their duties Jambi Province Early Childhood Education Development Center have functions 1) development of early childhood education and community education programs; 2) mapping the quality of early childhood education and community education; 3) supervision of early childhood education and community education units; 4) facilitate the preparation and implementation of early childhood education and community education programs; 5) development of early childhood education and community education resources; 6) management of information systems for early childhood education and community education; 7) implementing early childhood education and community education partnerships; 8) implementation of Early Childhood Education Development Center and Community Education administrative affairs.

In fact, the achievement of quality early childhood education programs is still low, this will have an impact on the low quality of education, while improving the quality of education must be carried out continuously and must not stop just waiting for the improvement of systems, facilities and human resources. 
The implication of the importance of quality has an influence on management practice because in the implementation of management there are ways to organize, guide and lead all those who are subordinates, so that the business that is being done can achieve the previously set goals which are managed comprehensively and integrated (Barnawi, 2017).

In Total Quality Management, customer satisfaction is prioritized, where the satisfaction is determined by the stakeholders of the institution. A stakeholder always tries to give satisfaction to society. In terms of management, customer satisfaction takes priority where the products are processed according to standards and specifications (Sallis, 2009).

To provide an overview and existence of quality management, Edwars Sallis, one of the TQM experts, emphasized that teamwork is a very important element and has fundamental strength. The team here means a group of people who work together and have the same goal of providing satisfaction to customers. Teamwork is very important in an organization because the cooperation will get optimal results by itself can increase the confidence of the team members. Confidence from more optimal results cannot be obtained, if no efforts are made continuously to improve and improve quality

Management in quality improvement is carried out in an integrated manner by involving all organizational components to make quality improvements in order to satisfy customers (Mullins, 2010). The notion of quality management is not just a system, organizational program, vision and mission that are displayed on the walls of the room, but also habits adopted by members of the organization as the life and personality of all members of the organization.

In order to guarantee the quality of early childhood education, the government has made early childhood education standards, as a reference or guideline on quality and how to maintain the quality of education itself in order to produce quality graduates. As stated in Minister Regulation Number 137 of 2014 which is used as a minimum reference in implementing early childhood education which is tailored to the needs of children's growth and development. In addition, there needs to be efforts from educational institutions and competent parties in the world of education to make it happen. These efforts start from how to prepare, implement and maintain the quality.

The application of quality management can produce guaranteed quality products. This management system pays attention to customer considerations, aspirations or desires. In addition, factors related to the production process are well managed in order to produce products that exceed consumer expectations. Quality of incoming raw materials is considered, the production process is closely monitored in order to avoid errors that can cause product defects. Until the product has been made, and before it reaches the consumer, the quality of the product is checked again whether it meets the criteria or not. All processes are closely monitored to ensure product quality.

The use of education quality management by the Early Childhood Education and Community Education Development Center in Jambi Province depends on how it positions existing early childhood education institutions as service institutions or also known as the service industry, which is an agency that provides services according to customer needs. The services or services needed by customers are of high quality and satisfying. Therefore, as an agency 
assigned to a provincial area that accommodates district education, it requires a management concept that empowers educational institutions to achieve and have quality.

As Allah SWT said in Surah Ar-Ra'd verse 11, verily Allah will not change the fate of a people, so they themselves change it. When education is seen as a sub-system of community life, its presence will be in line with the process of community development itself. If it is understood that education is integrated into an institutional form such as a school institution, which is an agency of social change so that it will form a system that is interrelated with one another.

Based on preliminary observations that we have observed in the field at the Jambi Province Early Childhood Education Development Center, it was found that the Program that had been compiled into an Annual Work Plan for which we asked for documents, including the vision and mission on display. On the wall inside are the efforts to improve the quality of Early Childhood Education, but their implementation in Early Childhood Education institutions is still a lot that has not reached the Early Childhood Education institutions in the regions, then researchers have also noted that in recent years on Jambi Province Early Childhood Education Development Center, their performance is still stagnant there is no improvement in achievement, Jambi Province Early Childhood Education Development Center are still accredited C, another problem is that Early Childhood Education institutions are not included in the results of the mapping and guidance of Jambi Province Early Childhood Education Development Center, the performance of the Early Childhood Education institutions is better, when compared to Early Childhood Education under the results of the mapping and guidance. Early Childhood Education development model to improve the quality of Early Childhood Education designed by Jambi Province Early Childhood Education Development Center has not been realized in all Early Childhood Education institutions, Making Jambi Province Early Childhood Education Development Center work programs that do not involve all competent parties in the Early Childhood Education field, access to online information at Jambi Province Early Childhood Education Development Center is inadequate so that it causes Early Childhood Education institutions to have difficulty accessing information on Early Childhood Education Development Center, there is still a lack of personnel at Jambi Province Early Childhood Education Development Center.

Early childhood is an individual who is experiencing a very rapid process of growth and development, so it is said to be the golden age, which is a valuable age compared to later ages (Isjoni, 2010). Based on this, Sriwahyuni et.al (2016) stated that early childhood education should be the main concern, not only for the government but at every level of society. Therefore the authors are interested in researching the management of the Early Childhood Education Development Center and Community Education in improving the quality of early childhood education in Jambi Province.

The objectives of this study 1) to find out why Early Childhood Education Development Center and Community Education have not been able to improve the quality of Early Childhood Education in Jambi Province; 2) to find out how the management of the Early Childhood Education Development Center and Community Education Partnership in improving the quality of Early Childhood Education in Jambi Province; 3) how to manage Early Childhood Education institutions in improving the quality of Early Childhood Education in Jambi Province; and 4) to find out how the management of Early Childhood 
Education Development Center and Community Education in improving the quality of Early Childhood Education in Jambi Province

\section{B. Methods}

This study used a descriptive qualitative method, with a phenomenological-naturalistic approach, where this research was carried out at Early Childhood Education Development Center and Community Education and the Early Childhood Education An-Nahl Percikan Iman educational institutions in Jambi City and Early Childhood Education Mutiara AlMadani in Sungai Penuh City. The research will present a report in a descriptive qualitative form. This is considered because qualitative research is more able to explore empirical social facts that occur naturalistically or contain the meaning of a phenomenon in the social setting under study (Moleong, 2010). So this approach is very meaningful in conducting qualitative research. Of course this approach is supported by direct involvement of the researcher, so that the information obtained in the research is truly accurate in accordance with the real situation of the social situation and the research subject.

For the research setting which is then applied by conducting research taking samples is Early Childhood Education An-Nahl Percikan Iman which is located at the intersection of IV Sipin, Telanai Pura District, west of the capital city of Jambi, with a distance of 5 kilometers from the capital city of Jambi Province. Based on geographic location, Early Childhood Education An-Nahl Percikan Iman is located in the City Center area, which is located west of Telanai Pura District (Jambi City Capital) with a distance of 2 kilometers from the Jambi Provincial Governor's Office.

Apart from Early Childhood Education An-Nahl Percikan Iman, Jambi City, the researchers also took the sample from Mutiara Al-Madani Early Childhood Education because these samples were both in two cities in Jambi Province. For Early Childhood Education Mutiara Al-Madani, Sungai Penuh City is located in Gedang Village, Sungai Penuh District, and its position in the City Center of Sungai Penuh

This research involved several informants who are expected to provide complete information about the management of Early Childhood Education Development Center and Community Education in improving the quality of Early Childhood Education in Jambi province. Some of the informants included the leaders of the Early Childhood Education Development Center and Community Education of the province of Jambi along with the head of the general division and staff, the coordinator of the learning community and members, representatives of the national accreditation agency Early Childhood Education in the province of Jambi, the provincial education office of Jambi, two districts which were sampled, namely the full river city and the city of Jambi as well as the An-Nahl Early Childhood Education institute the spark of faith in the city of Jambi and the Early Childhood Education Mutiara Al-Madani, a river city full of including parents of children.

Primary data was obtained in the field when the research was ongoing, the information obtained directly was in the form of spoken words from the head of the Center For Early Childhood Education, the sub-division head, the coordinator of the tutors and their members, the staff of Early Childhood Education Development Center and Community Education, the head of PAUDNI in Jambi, the head of Early Childhood Education in Jambi City, Early Childhood Education inspectors at the city education office in Jambi, Early Childhood 
Education district for Sungai Penuh city, Section Chief Early Childhood Education for Sungai Penuh city, supervisors at the full river city education office, head/educator Early Childhood Education An-Nahl Early Childhood Education city of Jambi, head/educator Early Childhood Education Mutiara Al-Madani, a full river city, assessors for early childhood education from the national accreditation agency in Jambi province, community leaders and also parents of children and other sources. Whereas secondary data, the data obtained does not directly provide data to data collectors, for example through other people or documents resulting from documentation and e-documents from Early Childhood Education Development Center and Community Education in Jambi province and also Early Childhood Education institutions, such as decrees, monthly reports, quarterly reports, annual reports, announcements, implementation guidelines, meeting minutes, pictures and so on.

To make it easier to identify data sources, the data sources in this study are classified into 3 forms 1) Human, the data source is in the form of a person, namely a data source that can provide data in the form of an oral answer through an interview or a written answer through a questionnaire. In this research, the data source in the form of person is; Head of Center For Early Childhood Education, Teacher, staff of Early Childhood Education Development Center and Community Education, Head of Jambi City PAUDNI, Head of Jambi City Early Childhood Education, Jambi City Education Office Early Childhood Education Inspectors, Sungai Penuh City Early Childhood Education Head, Sungai Penuh City Early Childhood Education Headquarters, Supervisor at the Education Office Kota Sungai Penuh, Head/Educator Early Childhood Education An-Nahl Jambi City, Head/Educator Early Childhood Education Mutiara Al-Madani Kota Sungai Penuh, Early Childhood Education assessors from the Jambi Province National Accreditation Agency, community leaders and also the child's parents and other sources; 2) Place, the data source is a place, namely the data source that presents a view in the form of a stationary and moving state. In this study, the role of data sources in the form of places is the Early Childhood Education Development Center and Community Education buildings, the head office, the teacher's room, the administration room, the Early Childhood Education institutions and so on; 3) Document, data sources in the form of symbols, namely data sources that present letters, numbers, pictures, or other symbols. Researchers took data from files in the Early Childhood Education Development Center and Community Education documentation and used them as data sources. Such as documentation regarding the data of the heads of Early Childhood Education Development Center and Community Education, data of teacher, data of staff and inventory data of facilities and infrastructure in Early Childhood Education Development Center and Community Education Jambi Province, as well as data found in Early Childhood Education An-Nahl Kota Jambi and Early Childhood Education Mutiara Al-Madani, the City of Sungai Penuh.

In this study, we used three techniques, because this research is in a qualitative form, the required data must be in the form of words, notes/writing actions, recordings, pictures, and others. In addition, in this study there is also a process of observing and interpreting the cases or problems that occur. Therefore, the data collected is in the form of in-depth interviews to collect information in the form of spoken words, observations to understand the attitudes that occur, and documentation in the form of writing, pictures, recordings, or photos (Sugiyono, 2015).

Before the field, we carried out an analysis of the preliminary study data or secondary data from books, journals and others that will be used to determine the research focus, however 
the focus of this research is temporary, and will develop after the researcher enters and during in the field. Activities in data analysis are carried out interactively and continuously until completion, so that the data is more saturated. Before the data is analyzed, all data is collected first, then it is reduced to be recorded carefully and in detail, the main things are selected to be used as themes. It is learned by looking at behavior, work methods, workplace conditions, interactions and what it does.

After that we entered the Early Childhood Education Development Center setting, the researcher moved to focus on Early Childhood Education Development Center partners such as the Jambi Province Early Childhood Education National Accreditation Board, the provincial education office, Early Childhood Education institutions and the community including parents of students. In reducing data, researchers are guided by the objectives to be achieved where the main objective of this qualitative research is the findings. After that, the presentation of the data can be in the form of a brief description, a chart, the relationship between categories and narrative text.

The next step is drawing conclusions, drawing conclusions or verifying data, of course the expected data is valid and quality data, so that the results of the research carried out are of high quality and good, however, the initial conclusions put forward are still temporary, and will change if not found. Strong evidence to support the next stage is data collection. But if the conclusions put forward at an early stage are supported by valid and consistent evidence when the researcher returns to the field of collecting data, then the conclusions presented will be a credible conclusion.

\section{Results and Discussion}

The initial activities of management the implementation of Total Quality Management starts from planning efforts to realize quality Early Childhood Education according to the needs and expectations of the community, especially parents of students to continue their children to school at the next level of education, as well as the development of children's potential according to the child's age.

In planning there are many things that need to be prepared, starting from establishing the vision and mission of Early Childhood Education Development Center and Community Education itself in improving the quality of Early Childhood Education, where in the vision and mission it is stated that the vision is to realize quality Early Childhood Education and Community Education services in forming intelligent people, tough, has good character, and has a noble character, as well as the mission. As supported by the findings Sanchez (2017) mission and vision are the most frequently used strategic planning tools. Vision is very important in strategic planning.

In general, there is a lot of discussion about improving the quality of services, one of which is improving the quality of service for the early childhood education program and the development of information systems development, implementing quality partnerships and so on.

The compilation of program plans is compiled and discussed in internal meetings of the Early Childhood Education Development Center and Community Education in the province of Jambi as conveyed by the head of Early Childhood Education Development Center and 
Community Education initials RH and confirmed by tutors usually meetings have started from July. Then Early Childhood Education Development Center and Community Education in their program planning to improve the quality of Early Childhood Education are program development through the development of a model created by a team of experts from tutors, academics, and practitioners. No less important in the work plan of Early Childhood Education Development Center and Community Education in improving the quality of early childhood education is the quality mapping program of 550 institutions that will be prepared to meet the National Early Childhood Education Standards. In the program plan there is also a human resource development program for tutors, institutional managers, and educators.

The next management step is organizing. As we know that making it easier to achieve goals is inseparable from the organizational structure and the authority it carries to run the wheels of an organization. The organizational structure already exists along with a job description consisting of the Head of the Center for Early Childhood Education, the Head of the General Sub-Division and 6 members of the Section Chief, and 11 tutors died 1 person, only 10 civil servants left. Especially for tutors, there is still a shortage of personnel with a large and wide area, while in Jambi province there are 11 districts while the existing civil servants number 10 people, each district should be 2 people, so for 11 districts there are 22 people.

Furthermore, from observations, the interviews conducted by researchers found that in the organizing section, the personnel placement arrangement was not perfect some were not in accordance with their educational background. The goal is that in terms of assigning each officer who carries out the task it is necessary to have an educational background and experience in the field of early childhood education so that the division of work is not carried out in an extreme manner which will cause fatigue and loss of motivation at work due to failure to understand the work at hand.

In the implementation section, each institution or organization has its own management. The emergence and development of an organizational institution, a very influential element is the qualification and style of the leader in that institution. Some of the programs have been implemented but there are still some that have not been carried out properly, especially in relation to improving the quality of programs that have been made should be implemented by $70 \%$ and expectations are in accordance with national Early Childhood Education standards.

Early Childhood Education quality can experience continuous improvement. From the results of interviews, observations and documentation conducted by researchers, it was found that budget management from the government for Early Childhood Education Development Center and Community Education was not used effectively and efficiently, even according to the head of Early Childhood Education Development Center and Community Education some of them were returned to the center even though if you want to be honest there is a lot that needs to be addressed, from monitoring is in the field because there are indications of ineffective and inefficient use of the budget, that is the following year the central government reduces the budget for Early Childhood Education Development Center and Community Education, in the implementation of the Early Childhood Education quality improvement program it has been carried out but there are still deficiencies this is due to lack of coordination with the Early Childhood Education Development Center and Community Education does not have smooth communication. 
In the end, there are programs that have been made by the provincial Early Childhood Education Development Center and Community Education such as making models that do not reach their distribution to existing institutions. Furthermore, there are still many programs for developing and improving the quality of personnel, including the competence of managers and teaching staff, who have never participated in training activities or workshops with the aim of gaining insight and increasing competence, out of the area but that the intensity is rarely done not intensely done.

Then in improving the quality of early childhood education, it is very important to access information openly to make it easier to get information, both from the central to the province and the regions in the city district, from the interviews we conducted with the Head of the General Subdivision regarding access to information, he admitted that not much can be done. We do it because our equipment is not modern and sophisticated and the resources that will be accessed are still few and he will improve it in the future to be even better.

In the implementation part concerning partnerships, it has not been fully established, if indeed the aim is to improve the quality of education, especially when compared to other provinces and regions, the province of Jambi, in the field of early childhood education, is far behind, from interviews we conducted with the national accreditation agency Early Childhood Education in Jambi province. For the accreditation of Early Childhood Education institutions, there are people from Center For Early Childhood Education who ask or order that Early Childhood Education Development Center and Community Education will choose who will assess and go down the field to see the institution's situation and provide an assessment, after we confronted Early Childhood Education Development Center and Community Education, on the other hand, said that it was Early Childhood Education National Accreditation Board that accredited Early Childhood Education institutions that were not yet feasible, in fact the Jambi Province Early Childhood Education National Accreditation Board gave a good assessment and entered the accreditation category.

Supposedly, if these two parties want to sit together to solve the problems that occur in the quality of Early Childhood Education today, it will not happen in the condition of Early Childhood Education in the province of Jambi, it can be said that only a few and a small part of Early Childhood Education institutions that have been accredited A. Private Early Childhood Education that are not coached by Early Childhood Education Development Center and Community Education in the province of Jambi, the Early Childhood Education institutions under their guidance should be of better quality. To achieve optimal success, there must be good cooperation from all parties related to Early Childhood Education, including the district education office and Early Childhood Education institutions which are the spearhead of the implementation of the quality of Early Childhood Education. The most important thing according to researchers and taken from existing management theories is very important communication is established with partners and subordinates. Because in integrated management to be able to provide satisfaction to consumers there needs to be teamwork which can have an impact on the performance and confidence of an institution or organization for optimal results obtained.

The last step in management is monitoring or evaluation, where monitoring and evaluation can produce innovation in managing an institution or organization. The accumulation of the results of observations, documentation and interviews that researchers conducted at Early Childhood Education Development Center and Community Education and Early Childhood 
Education An-Nahl and Early Childhood Education Mutiara Al-Madani institutions were found. From the internal Early Childhood Education Development Center and Community Education the intensity carried out by the head of Early Childhood Education Development Center and Community Education on the work of their subordinates is still not optimal and the control is still rare, even though if you want to get something or maximum results, of course the effort must also be maximal, the evidence is that there are still many Early Childhood Education institutions. There are still many who have not received a curriculum model prepared and designed by Early Childhood Education Development Center and Community Education, there are still many who have never participated in competency improvement training held by the Early Childhood Education Development Center and Community Education in Jambi province.

Supervision is needed in educational institutions (Kristiawan et.al, 2019). Supervision implies an activity to make observations for the work done in accordance with the provisions (Murtiningsih et.al, 2019). The purpose of supervision is to ensure that the programs and activities carried out have been running effectively or not. If not, where are the obstacles and as a guide for the next steps to make new innovations. If the supervision section is not maximally carried out, then for future quality improvement steps it will experience a place where the quality will even decrease.

The analysis of the research results shows that the management of Center for Early Childhood Education in improving the quality of Early Childhood Education in Jambi Province, improving the quality of Early Childhood Education in Jambi Province, cannot be separated from the role of human resources, in this case of course human resources in the institution. This is supported by Mukhtar et.al (2020) who stated human resources are one of the important components in improving the quality of education. Jambi Province Early Childhood Education Development Center because this institution is an extension of the Ministry of Education and Culture of the Republic of Indonesia, the Directorate General of Early Childhood Education as a Technical Implementing Unit in terms of improving the quality of early childhood education.

Early Childhood Education implementation has not been optimal, including; first, the factors of the Early Childhood Education Development Center and Community Education personnel are the lack of awareness of responsibility and failure to determine the authority and responsibility of Early Childhood Education Development Center and Community Education. Second, on the government side, the Early Childhood Education Development Center and Community Education personnel are not properly prepared to be sufficiently equipped to carry out their duties, for example, to qualify as employees at Early Childhood Education Development Center and Community Education educational qualifications are not a crucial consideration and may be from an educational background. Third, the government's lack of attention to education, especially early childhood education, should be a serious concern from the government, the evidence is that the participation rate is still low, eventually there is an inequality in education, especially with regard to quality assurance because the government places more burden on managing early childhood education. To society. That's why there is a term that early childhood education is education from the community and for the community. Especially for the substance of the budget to raise or develop an early childhood education institution, it focuses on the community; this is what has happened so far there is an education gap between cities and villages or urban areas and remote areas. 


\section{Conclusion}

The cause of the inability of the Early Childhood Education Development Center to improve the quality of early childhood education in Jambi Province, this is because Early Childhood Education Development Center and Community Education have not maximally implemented total integrated management starting from planning, organizing, implementing and monitoring and there are also many Early Childhood Education institutions in Jambi province that has not met the national standard of early childhood education. Management carried out by Early Childhood Education Development Center and Community Education in Jambi province that has not been maximized can be seen from the results that have not satisfied consumers, of course in this case the satisfaction of Early Childhood Education Development Center and Community Education service users (Early Childhood Education institutions, Early Childhood Education children, parents of children and the community at generally)

\section{E. Acknowledgement}

We want to thank God Almighty for completing this work, and with extraordinary gratitude for the opportunity, support given to us, especially to the Chancellor of Universitas Islam Negeri Sulthan Thaha Saifuddin Jambi, Advisor, Examiner and the Academic Community of Universitas Islam Negeri Sulthan Thaha Saifuddin Jambi, and all my colleagues who I cannot name one by one who have helped in the completion of this scientific work.

\section{References}

Asvio, N., Yamin, M., \& Risnita. (2019). Influence of Leadership Style, Emotional Intelligence and Job Satisfaction toward Organizational Commitment (Survey at SMA Muhammadiyah South Sumatera). International Journal of Scientific \& Technology Research 8 (8).

Barnawi and M. Arifin. (2017) Education Quality Assurance System. Yogyakarta: Ar-Ruzz Media.

Directorate General of External Education, Ministry of National Education. (2006). Future Investment PAUD. Jakarta: Director General of Early Childhood Education

Isjoni. (2010). Model Pembelajaran Anak Usia Dini [Early Childhood Learning Model]. Bandung: Alfabeta.

Kristiawan, M., Yuniarsih, Y., \& Fitria, H. (2019). Supervisi Pendidikan [Education Supervision]. Bandung: Alfabeta.

Moleong, L. J. (2010). Qualitative Research Methodology. Bandung: Rosda Karya

Mukhtar., Minnah, E., \& Padli, M. (2020). The Impression of Kiai's Leadership in Managing Islamic Boarding Schools. International Journal of Educational Review, 3 (1).

Mukhtar, L., \& Suryawahyuni L. (2018). Educational Management Theory. Jakarta: Golden.

Mullins J. Laurie, (2010). Management and Organizational Behavior. England: Prentice Hall, Pearson. 
Journal of Social Work and Science Education

Volume 1 (2) 2020

E-ISSN: $2723-6919$

Mulyasa, E. (2011). Manajemen Kepala Sekolah dan Kepemimpinan [Principal Management and Leadership]. Jakarta: Bumi Aksara.

Murtiningsih, Kristiawan, M., \& Lian, B. (2019). The Correlation between Supervision of Headmaster and Interpersonal Communication with Work Ethos of The Teacher. European Journal of Education Studies 6 (1).

Sallis, E. (2009). Total Quality Management in Education. Yogyakarta: IRCiSoD.

Sanchez, J. D. C. (2017). Mission and Vision Statements of Universities Worldwide - A content Analysis. Escuela de Administracion, Documento de Investigacion, 152.

Sriwahyuni, E., Asvio, N., Nofialdi. (2016). Metode Pembelajaran yang Digunakan PAUD (Pendidikan Anak Usia Dini) Permata Bunda [Learning methods used by Permata Bunda PAUD (Early Childhood Education)]. Thufula: Jurnal Inovasi Pendidikan Guru Raudhatul Athfal 4 (1).

Sugiyono, (2015). Memahami Penelitian Kualitatif [Understanding Qualitative Research]. Bandung: Alfabeta.

Tobari., Kristiawan, M. \& Asvio N. (2018). The strategy of Headmaster on Upgrading Educational Quality in Asean Economic Community (AEC) Era. International Journal of Scientific \& Technology Research 7 (4). 